\title{
An Overview Focusing on the Relationship between Vocational Education and the Necessities of Turkish Business
}

\author{
By Tolga Yazici*
}

In the $21^{\text {st }}$ century, economic competiveness has reached a considerably high level and the quality of goods and services that are produced have become the most important criteria of measuring the economic performances of countries. It is also acknowledged that this economic development is essentially based on the existence of a qualified labour force. Indeed, the only possible way to create a qualified workforce is through qualified educational strategies. Eventually, the existence of viable strategy of vocational education is a prerequisite for a strong economy. Until quite recently, the vocational education institutions in Turkey have been quite inefficient due to lack of quality and communication between these educational institutions and the organizations or companies which were expected to employ the people that studied in these schools. This study aims to examine the problematical communication between vocational education institutions and business circles and also tries to review the practices being held to solve this problem.

Keywords: business, education, employment, labour force, technical vocational

\section{Introduction}

Education is essential for these individuals to evolve and this education isonly possible through vocational and technical education given to the intermediate staff in the business markets. Vocational and technical education can be defined as "a process of mental, emotional, social, economic and personal development of an individual through the knowledge, abilities and practical application skills that an occupation necessitates in the context of personal and social life" (Mesleki ve Teknik Eğitim Strateji Belgesi ve Eylem Planı (Taslak) 2013-2017).

Today, the level of developed countries is determined according to their human resources. Qualifications, fast learning, analytical thinking skills, adoptability to unstable conditions and the problem solving capacity of human resources affect the developmental level of countries directly. Although education is the most important factor in the development of people, ideologies and quality of education may vary depending on the conditions of a country. Every country should apply appropriate education policies according to their inner dynamics so that useful and qualified persons can raise themselves both individually and socially.

\footnotetext{
* President and Chairman, Plato Collage of Higher Education, Turkey.
} 
Significantly, in the recent years, transformations in the processes of production and consumption make it clear that the most important component of these processes is the human being. It is through qualified employees that countries can prove their existence in international arenas and stay in the sectorial competition game. So it is essential for educational institutions to follow policies that contribute to a country's economy and satisfy the needs of the labor market.

Due to poor quality in both primary and secondary schools, and vocational and technical schools or universities, the skills of young people educated in those institutions cannot satisfy the expectations of the organizations, which do not only have difficulties in the recruitment process but also they must provide extra training for those recruited. This costs time, labor force and expenditures for both the employee and the employer. For this reason, business world and educational institutions have to work cooperatively in providing "qualified employees", especially for the needs of the labor market, and also to apply education programs by strengthening the dialogue between the business world and educational institutions.

The education programs that are created through the cooperation of the business world and the educational institutions are important in the meeting of the expectations of both the employers and the employees. Today, many countries in the world aim at improving the quality of their human resources with these cooperation programs. Although these programs have been adopted in Turkey as well, there are still some problems due to lack of communication between the business world and educational institutions.

Turkish economy improves day by day. In the past ten years, the Gross National Product in Turkey has gotten seven times larger and has become more than 800 billion dollars (Metek Bulletin 1 2014). Turkey, which is already in the top twenty largest economies in the world, aims at entering the top ten. This is only possible with an appropriate export and import volume, thus with a qualified and skilled labor force. For this reason, future strategy plans on vocational education institutes and Vocational Schools of Higher Education should be designed according to the need of the labor market and through strengthening the cooperation with the business world.

\section{Vocational Technical Education and Vocational Schools of Higher Education in Turkey}

It is already recognized in the recent past that the key to economic development both in Turkey and in the world is a qualified labor force. It is through the qualified employee's value that they gain and contribute to the organization that the organization can prove itself and develop its position in the sector. The most important aspect in the recruitment of qualified employees is education. Thus, for the labor force to contribute value to the organization and adjust the competition in the sector, employees with the skills mentioned 
below should be recruited (Vocational and Technical Education Strategy Document and Action Plan (Sketch) 2013-2017, 2014):

- appropriate to the current demands,

- adjustable to the changes,

- having basic academic skills (such as the knowledge of reading, writing, mathematics, science etc.)

- able to take initiatives,

- knowledge of foreign languages and high communication skills.

Vocational and technical education is received after compulsory education in the world. For this reason, vocational technical education starts at the secondary school level and continues in the Vocational School of Higher Education (VSHE).

VSHEs are the most important institutions where qualified employees necessary for the business world are trained both in Turkey and in the world. Especially in the industrial sector where the intermediate staff is needed and it is provided from VSHEs instead of the other academic institutions. The importance of the vocational technical education increased as much as the academic education after this was realized in the world. However, up until the recent years in Turkey vocational technical education remained under the shadow of academic education and VSHEs were not taken as seriously as they were supposed to be in the educational policies. For this reason, those who had graduated from VSHEs could not acquire enough accumulation of knowledge and could not satisfy the needs of the business world with their practical knowledge skills.

The graduates of Vocational High Schools usually prefer VSHEs and this is also arranged in the current education system. The VSHEs are determined to get connected to the universities according to the Law No. 2547 (year 1981), which asserts that all higher education institutions must be concentrated at one hand. Passage "g" of the third item of the same law defines VSHEs as "a higher education institution, which concentrates on vocational training" (Higher Education Law No. 2547 2014). The Vocational Education Law No. 3308, which was enacted in 1986, became a turning point for the future of vocational education. Accordingly, vocational and technical schools and institutions were reformed based on the cooperation with the organizations (Vocational and Technical Education Strategy Document and Action Plan (Sketch) 2013-2017, 2014).

VSHEs can be founded by both state universities and private ones. Other than these, private based VSHEs can be founded without needing the support of a university. However, neither state based nor private based vocational education programs are sufficient enough to satisfy the needs of the labor force market in Turkey. This, to a great extent, is because of the lack of communication and dialogue between the business market and educational programs. This situation was marked as following in the Medium Term Report of the State Planning Organization (Şengel 2011): 
"In order to produce a qualified labor force according to the demands of the labor force, mechanisms will be created to strengthen the cooperation between the education and the labor force.

Lifelong education strategies will be prepared.

Due to the transition to the information society, considering the local, national and international developments and needs, the units and programs of the higher education institutions will be renovated.

The private sector will be motivated to contribute to the funding for the activities that will train the qualified labor force".

The number of the vocational education institutions in Turkey increases day by day but this quantitative increase cannot compensate qualitative insufficiencies. According to the "Vocational Schools of Higher Education in Turkey", a report prepared by Prof. Dr. Durmuş Günay, Council of Higher Education (CHE) Executive Committee Member and Prof. Dr. Mahmut Özer (2014), CHE VSHE Study Group Coordinator and the President of Bülent Ecevit University, the number of VSHEs in Turkey exceeded 800 in the year 2014. Other information in the report is as follows:

"Out of 802 vocational schools of higher education in Turkey, 705 or $88 \%$ belongs to state universities, 57 or $7 \%$ belongs to foundation universities, 8 or $1 \%$ belongs to foundation based VSHEs, 32 or $4 \%$ belongs to other VSHEs. Out of all these VSHEs, 549 divide their education programs into two as technical and social, and 253 provide training in twenty different thematic fields such as health, tourism, areal sciences, law, mining, transportation, etc.

The number of associate degree students, including those who study associate degrees in Distant Education Programs, reached 1 million 527 thousand 706 in 2013. That is to say, $30 \%$ of higher education students study at VSHEs. In 2013 $50.9 \%$ or 777 thousand 74 of associate degree students are at VSHEs and $49.1 \%$ or 749 thousand 965 study at distant education associate degree programs.

$90.6 \%$ of 777 thousand 741 VSHE students are at state universities, $5.7 \%$ of them are at foundation universities, $0.9 \%$ and $2.8 \%$ are at foundation based and other VSHEs".

An increase in the opportunities for the recruitment of young people in Turkey, where the young population holds an important scale, is expected. However, there are many current problems along with the need for improvement of the vocational secondary schools and VSHEs. 


\section{Problems Related to VSHEs}

Although vocational training is considered as a sub branch in the context of general education, it is different than general or academic education. The goal of general or academic education is mostly to teach analytical knowledge, skills and critical thinking, whereas vocational training aims at teaching crafts, practical experiences and problem solving skills (Aydınkal et al. 2012). However, both in the education system of vocational high schools and the educational programs of VHSEs, these differences are mostly ignored.

Today, there is no examination system for entering VHSEs in Turkey. Nevertheless, now, there should be a different examination system for the students who have graduated from vocational high schools. That is to say, at the entrance to the vocational technical education system, the students should be given professional guidance and the student's relevant skills, desire for the relevant occupation and other side factors should be taken into consideration (Şahinkesen 1993). Law No. 4702, which accords a right for the students who have graduated from vocational high schools to enter VHSEs directly, without having an exam, caused breakdowns in the operations of VHSEs. This right for entering VHSEs without going through an exam turned VHSEs into something that many students use just in order to be able to write "college graduate" on their curriculum vitas.

Along with these problems, it is well known that many VSHEs which are currently active in Turkey lack adequate facilities like school buildings, atelier, lab, stationary and equipment. They also lack in academic personnel who could teach at these schools. VSHEs have many problems due to the needs of the system and their own inner dynamics. However, the most important problem of all is that VSHEs fail in fulfilling their major aim, that is, "to provide a qualified staff that would satisfy the needs of the business market".

The key to the success of VSHEs is their capability of training the staff by establishing cooperation between vocational training and the business market. Nevertheless, because there is no consensus on programs between vocational and technical secondary schools and VSHEs, vocational and technical education programs are not updated according to the demands and needs of the labor force market, employees who had gone through vocational training are not recruited appropriately and this gives way to the decline in the demand for vocational training (Aydınkal et al. 2012).

There are serious attempts going on in Turkey in implementing vocational education programs, which are designed according to the needs of the labor force market in order to establish an accomplished relationship between the labor force markets and the VSHEs, and continuing a reciprocal dialogue. These attempts cannot be fulfilled until Turkey's becomes one of the largest economies of the world by using its potential of a large young population and until it satisfies the needs of the business world by providing a qualified labor force. 


\title{
METEK Project
}

The Turkish Ministry of Education has been carrying out attempts to eliminate the deficiencies in the education system and renovate the current program according to the current needs for almost twenty years now. With this purpose, in 2002 with the support of the European Union "The Project for Improving the Vocational Education System in Turkey (MEGEP)", in 2003 "The Project for Modernizing the Vocational and Technical Education in Turkey (MTEM)" were accomplished. The most recent one of these projects is METEK, which was actualized in 2013. The project METEK is generally about implementing the sense and process of quality of the VHSEs in European countries into the VHSEs in Turkey through the Project for Improving the Quality of Vocational and Technical Education in Turkey.

Education stands as an important category of the Europe of 2020 strategy along with the five parallel goals; recruitment, social inclusion, researchdevelopment, climate and energy, which are all in the context of smart, sustainable and encompassing growth priorities. This is possible with the strategy of "Education, vocational education and lifelong learning", which is in the focus of smart growth strategy (Akbaş and Apar 2010):

\begin{abstract}
"With the initiative of the quality of education and vocational training at any level in Europe and the opportunity for youth recruitment is aimed to be increased along with the performance of the higher education institutes and their attractiveness in the international arena through student and apprentice exchange programs. The flourishing job opportunities for the young people through inclusion of the youth to the labor market by decreasing the rate of unemployment and creating chances for them to get job experience through apprenticeship and traineeship and encouraging the mobility in the EU is anticipated".
\end{abstract}

METEK, has been implemented in the context of this understanding, the goal is to "carry out teachers' training, curriculum development and raising awareness among the public opinion regarding the improvements in the vocational training" (Metek Bulletin I 2014) through implementing an applicable, measurable and sustainable national quality guarantee in the vocational training in 21 sample cities and 50 sample vocational and technical education institutes. For this reason, one of the major priorities of METEK is the development of the education modules by considering the labor force market analyses of the Turkish Employment Agency (ISSKUR). METEK is in cooperation with institutions like Higher Education Council, Central Administration Institute, Ministry of Education, Turkish Employment Agency, Ministry of Labor and Social Security and Ministry of Industry.

One of the most important steps of METEK activities is quality management. With this purpose, the "Sample Vocational and Technical Education Quality Strategy Report" (Metek Bulletin II 2014) was prepared. 
According to this report the functions of vocational and technical education quality are determined as follows:

"Leadership, administration and finance

Employee Recruitment, selection and development (including education)

Providing educative materials and staff as a support for the students.

Accessing and participating VSHE programs

Measurement and Evaluation process

Demand based curriculum preparation (in cooperation with the sector)

Program design

Vocational counseling and guidance

Quality improvement

The frame of qualification and lifelong education

Entrance to the higher education"

For these principles to become functional, VSHEs to reach the European Union quality standards and to establish a working relationship between the VSHEs and the business world, a series of studies, plans, workshops and conferences started to be conducted. The results of these workshops were presented in "Building Reciprocal Trust Between the Business World and Vocational Education" conference in 2013. Conferences, workshops and applications like this one are very important in the sense that they gather the business world and the VSHEs together, highlight the problems between the VSHEs and the business world and suggest solutions to the problems to improve the mutual relationships.

\section{Business World-Vocational Education Cooperation Project: "Vocational Education, National Matter"}

The project of "Vocational Education, National Matter (MLMM)" of the Koç Group in 2013, which is one the most important companies in Turkey and owns an endorsement of $10 \%$ of Turkey's total exportation and $8 \%$ of the National Income, in cooperation with the Turkish Ministry of Education and the Vehbi Koc Foundation, stands out as a significant step towards the future of the VSHEs. The project had been conducted since 2006 and it has been awarded both in national and international platforms.

The project's foundation is the "School-Business Union Model" and the Koc group activated scholarships, curriculums, labs, apprenticeship, vocational high school guidance and vocational education and recruitment in the context of this model. In these regards, as an integrated part of the Koc Groups vocational education investments and human resources policies (Tunçalp 2013) "8 companies of the Koc group founded 29 labs, 7 education centers, 1 vocational high school and 1 vocational school of higher education in five sectors through micro projects". The results of the projects that are defined as a seven-year long work plan in 2006-2013 are as follows: 
An important step towards the future of vocational education was taken with funding, vocational high school coaching, priority of apprenticeship and recruitment, micro projects addressing the needs of different sectors, communication campaigns to create and increase awareness among the public opinion, cooperation of the entrepreneurs and competitions that would contribute to the vocational and personal development of the students.

Between the years of 2006 and 2013 more than 8 thousand students from 264 different schools in 81 cities were given funding. The number of the students studying at the vocational high schools increased to $68 \%$, almost 2500 students found supplementary education opportunities in different branches and the number of the companies that had contributed to the project or developed similar projects had gotten close to fifty.

"Vocational Education, National Matter" project of the Koc Group and concrete results of this project became effective in changing the views of the business world as well as potential students and their families regarding the vocational education along with setting as an example in establishing and continuing an appropriate relationship between the business world and the vocational education in Turkey.

\section{A Successful Example of the Vocational Education: Dual System}

Dual education is a system of education implemented in Germany for educating young people to take over the positions left by highly knowledgeable and skillful employees who had to leave their job due to their ages. One of the most important features of this system is that the dual education is carried out in cooperation with chambers of commerce and industry and the business market. The German dual system is integrated to the study as an example for the problematic of the work in order to derive information regarding the necessity of cooperation between the business market, the education system and the success of this sort of a study.

Compulsory education in Germany is usually for 9 years and even 10 years in some states. Vocational training is carried out only after the compulsory education. Vocational training can be applied in two forms, as full time vocational training or as a dual system. Nevertheless, the ratio of dual system students, who spend 3 to 4 business days at the companies, is $50 \%$, while the students of the full time vocational high schools hold only $15 \%$ of the entire whole (Özdemir 2011a). This statistical datum is important in showing the ratio of the preferability of the dual system in the current education system.

The structure of the German dual vocational education is shown in the Figure 1. 
Figure 1. German Dual Vocational Education System

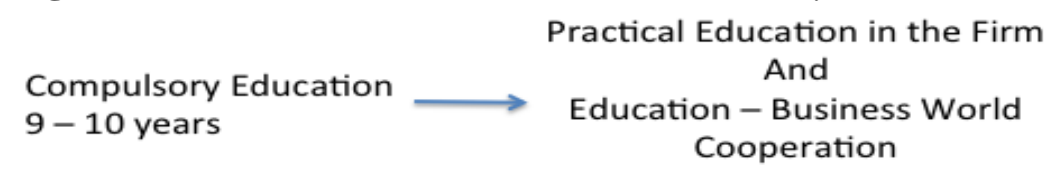

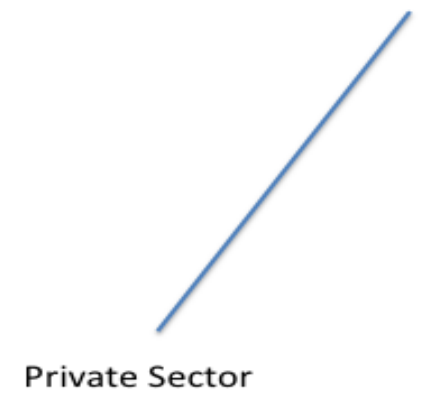

Private Sector

Source: E Özdemir $2011 \mathrm{~b}$

The legal grounds of the dual system was secured by the Vocational Education Law of 1969 and reached its current condition in 2007, when it started to be implemented as a $2.5-3$ or 4 years long education by encompassing 346 professions. On the grounds of the center lie units like the Chamber of Commerce and Industry, the Union of Chamber of Merchants and Craftsmen, Chamber of Agriculture, Chamber of Lawyers and Chamber of Doctors, which are authorized by the Vocational Education Law and act as intermediaries between the business market and education institutions (Özdemir 2011a). The major tasks of these institutions are creating recruitment opportunities for the students who are studying at the vocational schools along with analyzing the needs of the business markets and helping establish substructures and equipment for these institutions to train appropriate staff for satisfying the needs.

The primary objective of the dual system is to establish cooperation between the education and the business world. For this reason, the relevant chambers and commissions have the following responsibilities (Özdemir 2011b):

"Approving the enterprises where the students will work as apprentices,

Inspecting the education process in terms of the content and the time,

Counseling for the firms and the apprentices,

Exams, evaluation and certification of the apprentice students,

Recording the contracts

Career counseling" 
These responsibilities are important for the system to operate better, meet the future aspirations of the business world as well as to educate the students.

The German dual system is an example for the vocational and technical education in Turkey. Although it has been tried in many developed and developing countries, the most successful example of the dual system is in Germany. On the grounds of this success lie the public and private sector, chambers and commissions and the cooperation with the educative institutions and their effective works on the form and applicability of the education system. Today in Turkey, similar cooperation attempts are taken place and strategies for making grounds to develop a healthier communication between the business world and the education institutes needs to be produced. In these regards, E. Ozdemirs studies on the Turkish and German vocational education system should be taken into consideration for applying a more effective vocational training.

Table 1. Vocational and Technical Education System: Comparison of Germany-Turkey

\begin{tabular}{|c|c|}
\hline GERMANY & TURKEY \\
\hline $\begin{array}{l}\text { UNITARY STRUCTURE } \\
\text { Responsible Institution: } \\
\text { Federal Vocational Training Institute }\end{array}$ & $\begin{array}{l}\text { PARTIAL STRUCTURE } \\
\text { Responsible Institution: } \\
\text { Various General Directorates of the Ministry of } \\
\text { Education }\end{array}$ \\
\hline $\begin{array}{l}\text { VOLUNTEERING PRINCIPLE } \\
\text { Basics of the System: } \\
\text { Volunteering, Vocational training is not an } \\
\text { obligation; enterprises are free for providing skills } \\
\text { education (vocational training) for the students. } \\
\text { Only the enterprises, which are willing to do so } \\
\text { and are approved by the chambers along with } \\
\text { having proper facilities, can provide applicable } \\
\text { vocational education for the students. In this } \\
\text { context, the enterprises that have proper teachers, } \\
\text { workplace and equipment can provide vocational } \\
\text { training. 25\% of all enterprises in Germany offered } \\
\text { vocational education. }\end{array}$ & $\begin{array}{l}\text { OBLIGATION PRINCIPLE } \\
\text { Basics of the System: } \\
\text { It is an obligation. Providing vocational training is } \\
\text { an obligation for the enterprises. } \\
\text { Enterprises where ten or more people are working, } \\
\text { are obliged to provide skill education for students } \\
\text { no less than } 5 \% \text { and no more than } 10 \% \text { of the } \\
\text { number of their current employees, pay those } \\
\text { students } 30 \% \text { of net minimum wage and found an } \\
\text { education unit if they are providing skill education } \\
\text { for ten or more students. } \\
\text { Although in the past only the enterprises that had } \\
20 \text { or more employees were obliged to offer skill } \\
\text { education, with the Law No. } 6111 \text { the number was } \\
\text { reduced to } 10 \text {. With the decision of the cabinet, this } \\
\text { number can be reduced even to five. Also, with the } \\
\text { Law No. } 6111 \text { the minimum wage to be paid was } \\
\text { determined as "net" and the uncertainty about } \\
\text { "net" or "gross" was resolved. }\end{array}$ \\
\hline $\begin{array}{l}\text { THERE ARE INCENTIVES } \\
\text { System of Incentives: Two way } \\
\text {-There are activities supporting and } \\
\text { complementing vocational training in the } \\
\text { enterprises (like JOBSTARTER program or Above } \\
\text { Enterprises Education Centers etc.) } \\
\text {-Direct support for the enterprises (partially } \\
\text { affording the expenses, sometimes monetary aids } \\
\text { etc.) }\end{array}$ & $\begin{array}{l}\text { THERE IS NO INCENTIVE } \\
\text { System of Incentives: There is no incentive. } \\
\text { There are enforcements instead of incentives. The } \\
\text { enterprises that do not offer skill education for the } \\
\text { students are supposed to deposit the } 2 \backslash 3 \text { of the } \\
\text { minimum wage per students that they had to recruit } \\
\text { to the account of the payroll division. On the other } \\
\text { hand, the determination of the minimum wage as } \\
\text { "net wage" gave way to a decrease in the payments } \\
\text { because it used to be a "gross wage." Besides, in } \\
\text { the year } 2011 \text { theAction Plan of The Recruitment } \\
\text { Technical Committee, a rule regarding to } \\
\text { encourage founding an educative unit and } \\
\text { recruiting teachers instead of enforcements was } \\
\text { asserted. }\end{array}$ \\
\hline
\end{tabular}




\section{CHAMBERS HAVE CONCRETE DUTIES \\ THAT ARE ASSIGNED BY LAW}

The role of the chambers: They are at the center of the system.

-Evaluating the properness of the enterprise,

-Following up and controlling the process,

-Arranging the examination and certification for the students,

-Recording the internships,

-Offering pedagogical formation for the teachers at the enterprises and documenting it.

In these regards, it is impossible to operate without having chambers.

\section{LONG TERM}

Education period: 2,5-3,5 years.

By this way, the student grows into a real worker and secures a mutual trust between the employee and the employer.

If trust was not established then the contract can be waived during the trial period.

\section{EFFECTIVE CONTROL AND FOLLOW UP}

Control and Follow Up Mechanism: The main element is the chambers.

Vocational training in the enterprises are controlled and followed up by the advisors of the chambers in the enterprises. The advisors are also looking for solutions to any problems that the enterprises and the students may run into.

EXAMS ARE UNDER THE AUTHORITY OF THE CHAMBERS

Regulation of the Exams: It is the duty of the chambers.

In the exam commissions of the chambers there are representatives of the employers and the employees along with teachers.

\section{CHAMBERS DO NOT HAVE DUTIES BY LAW}

The role of the chambers: They have secondary roles in the system.

Legal duties, in the form of "developing and directing vocational and technical education" Concrete activities regarding this:

-Representation in the Municipality Recruitment and Vocational Education Institutions,

-Preparing vocational standards,

-Conveying the problems and views to the relevant offices.

Nevertheless, with the UMEM Skill '10 project, the role of the chambers, in need analysis of the labor force market, intern demand, recruitment and widespread vocational education was strengthened to a great degree.

\section{SHORT TERM}

Education period: 300 hours during the secondary school

This period is equal to almost two months. It does not give an opportunity for the students and the teacher to get used to each other.

In the vocational high schools: the skill education in the enterprises is carried out as two days at the school and three days at the enterprise for 864 hours during the $12^{\text {th }}$ grade.

\section{THERE IS NO REAL CONTROL OR FOLLOW} $\underline{\mathrm{UP}}$

Control Mechanism: Work inspectors are a part of the general control but it cannot be wholly applied. Other than that, there is no special control mechanism.

\section{EXAMS ARE UNDER THE AUTHORITY OF} THE MINISTRY OF EDUCATION (MEB)

Regulation of the Exams: It is MEB's duty. In the end of the year skill exam coordinated by MEB there are teachers, master trainers and the educative staff of the enterprise and the representatives of employment institutions in the city town. But there is not enough information regarding an effective operation.

THERE IS NO QUALITY ASSURANCE

THERE IS QUALITY ASSURANCE

Quality Assurance Mechanism:

Quality is assured through education directions prepared by FMME and the education plan that is prepared by the enterprises and checked by the chambers for any kind of profession, and according to the needs of the enterprise some sort of flexibility is also given. GUIDANCE AND COUNSELING IS STRONG Guidance and Counseling System: Guidance starts after the primary school. Students are sent to schools in different levels according to their capabilities. Before entering the dual education, the students are given appropriate education that would direct them into the schools according to their personal skills in the general education system (in the 5th and 6th grades).
Quality Assurance Mechanism:

There is no quality assurance mechanism developed for the skill education in the enterprises. The enterprises can assign duties (like serving tea, cleaning etc.) to the students unrelated to their professions.

\section{GUIDANCE AND COUNSELING IS}

\section{RESTRICTED}

Guidance and Counseling System: only counseling classes and teachers.
There is no specific education for this. There are 


\section{UNITARY STRUCTURE IN THE STANDARDS OF THE PROFESSIONS \\ Preparation of the Standards of the Professions: Professions are approved by FMME and their contents are created by FMME in cooperation with the employment institutions.}

\section{DUAL STRUCTURE IN THE STANDARDS OF} THE PROFESSIONS

Preparation of the Standards of the Professions: Dual Structure.

The standards of the professions are prepared by organizations in the sector (like chambers, unions etc.) in cooperation with the Professional Qualification Institution while the curriculum is created by MEB.

\section{Conclusion}

Today one of the most important indicators of the developed economies of the world is human resources. This view has been supported by statistical data in many studies. Education is the key to train a qualified labor force that the countries are in need of. Education institutions should be formalized by considering the inner dynamics of the countries and the place that the relevant country holds in the context of the world economy. Vocational training institutions are the most important means for providing the skilled labor force which countries need, and therefore should be programmed and sustained according to the needs of the sectors that they would be placed into.

A strong communication between the vocational training institutions and the business world should not be considered a choice but a necessity. This will give way to an improvement in the skills of the students who would graduate from vocational education institutions and VSHEs along with contributing to the strengthening of the business world and the creation of a more active recruitment process. In this regard, the dual system, which is applied in Germany, sets as a successful example for others to emulate. Projects that would improve the effectiveness of the education institutions by strengthening the communication between the labor force market and the education institutions are applied in Turkey as well as in other parts of the world. However, these projects fail occasionally due to the lack of interest of the business world or the education institutions' lack of substructure for this cooperation.

More than twenty years, a variety of projects were brought to fruition in Turkey to highlight the position of the vocational and technical education institutions and VSHEs among the other education institutions, and to satisfy the needs of the business world by recruiting the students who graduate from these schools according to their skills. Although these projects are considered to be highly significant steps taken towards the realization of the importance of vocational training and the satisfaction of the needs of the labor force markets, keeping the development process and future strategies of the country in mind they seem to be insufficient. 


\section{References}

Akbaş G, Apar A (2010) Avrupa 2020 Stratejisi: Akıllı, Sürdürülebilir ve Kapsayıcı Büyüme için Avrupa Stratejisi Özel Bilgi Notu [Well advised, sustainable and inclusive growth strategy for the European private information note]. Başbakanlık Avrupa Birliği Genel Sekreterliği Sosyal, Bölgesel ve Yenilikçi Politikalar Başkanlığı, Ankara.

Aydınkal M, Bilgin M, Şanöz F, Demirci D (2012) İstihdam Odaklı Mesleki Eğitim İçin Sektörel Talep Araştırması [Well advised, sustainable and inclusive growth strategy for the european private information note]. Orta Karadeniz Kalkinma Ajansl.

Günay D, Özer M (2014) Türkiye'de Meslek Yüksekokulları [Vocational schools in Turkey]. Retrieved from http://bit.ly/1MnKK7C. [Accessed 20 December 2014].

Mesleki ve Teknik Eğitim Strateji Belgesi ve Eylem Planı (Taslak) 2013-2017 [Document of vocational and technical education strategy and action plan]. Retrieved from http://bit.ly/1WfkZuJ. [Accessed 27 November 2014].

Metek Bülten I (2014) Milli Ĕgitim Bakanlı̆̆ Yayınları [Ministry of Education Publications] Retrieved from http://bit.ly/1KJK21Z. [Accessed 12 November 2014].

Metek Bülten II (2014) Milli Ĕgitim Bakanlı̆̆ Yayınları [Ministry of Education Publications]. Retrieved from http://bit.ly/1QvlA7Z. [Accessed 12 November 2014]

Özdemir E (2011a) Alman Mesleki Eğitim Sistemi ve Türkiye ile Karşılaştırılması I-II [German Vocational Training System and Comparison With Turkey]. Ekonomik Forum: 42-49, 72-76.

Özdemir E (2011b) Alman Mesleki Eğitim Sisteminde Özel Sektörün Rolü ve Ülkemiz Mesleki Eğitim ve Oda Sistemi için Çıkarımlar [The Role of the private sector in German vocational education system and examples for the vocational education and chambers system in our country ]. TOBB AB Daire Başkanlığı.

Şahinkesen A (1993) Mesleki ve Teknik Eğitimde Eğitim Teknolojisi [Vocational and technical education at educational technology]. A.̈̈. Ë̈itim Bilimleri Fakültesi, Ĕgitim Bilimleri Birinci Ulusal Kongresi, Bildiriler I Eğitim Teknolojisi, Ankara: 65-75.

Şengel S (2011) Türkiye'de Muhasebe Meslek Elemanı Talebi Üzerine Bir Araştırma [A survey on the demand of accounting professionals in Turkey]. Muhasebe ve Finansman Dergisi: 167-179.

Tunçalp K (Ed) (2013) Mesleki Eğitimin Ulusal-Uluslararası Rekabete Açılması ve 'Zamanın Ruhunu Okumak' [National, international competition opening of vocational education and 'Reading the Spirit of the Time]. Koç Topluluğu Kurumsal Sosyal Sorumluluk Raporu 2013, s.40-45. Retrieved from http://bit.ly/1QVVFqH. [Accessed 19 December 2014].

2547 Sayılı Yükseköğretim Kanunu [Higher Education Law No. 2547] (2014) Retrieved from http://bit.ly/1JmtBXk. [Accessed 14 December 2014]. 
